\title{
Effect of service quality on student-inspector satisfaction at the training center for educational inspectors in Rabat, Morocco
}

\author{
Mohamed ESSAOUDI ${ }^{1}$ and Raja LOTFI ${ }^{2}$ \\ ${ }^{1}$ Department: Management and Governance - Inspectors Training Center for Teaching (CFIE) - Rabat, Morocco. \\ ${ }^{2}$ Department: Management Techniques, Laboratory for Research in Organizational Management (LAREMO), \\ Higher School of Technology (EST), Hassan II University, 20020 - Casablanca, Morocco.
}

\begin{abstract}
In theory, we all know that if students are satisfied, then training centers do provide a better quality of service. But what about in practice? The purpose of this research is twofold. On the one hand, we aim to assess the quality of training inspectors in Morocco, through perceived quality and student satisfaction. First, we investigate which quality attributes need to be further targeted in the training device (TD) at CFIE. Second, we test for potential causal relationships between perceived service quality and student satisfaction. Our starting assumption is that there is a causal link between "service quality" and "satisfaction." To this end, the SERVPERF tool was adapted and administered to a sample of student inspectors who received training services at the CFIE in Rabat. We support the literature's argument that performance (SERVPERF) is the best predictor of service quality. The results shows that the perceived quality of services provided by CFIE is relatively acceptable. Nevertheless, it shows a strong need for improvement, especially in the dimensions of Tangibility and Empathy. All five dimensions of SERVPERF significantly impact student-inspector satisfaction at CFIE. The SERVPERF scale is a valuable aid in the institutional assessment of the TD, and in the implementation of a culture of continuous improvement within the CFIE. However, when used alone, it can lead to the omission of other factors that explain satisfaction. It would therefore be appropriate to couple it with other instruments such as SERVQUAL, HEDPERF, PAKSERV or HiEdQUAL in order to verify which ones are adapted to the context of education inspection in Morocco.
\end{abstract}

Keywords: Service quality, Student satisfaction, Perceived quality, SERVPERF, Training inspectors in Morocco.

\section{INTRODUCTION}

The issue of service quality in higher education is recurrent in international and Moroccan debates. In spite of being always the concern of managers and academics, the service quality is today a tool used by many universities, in order to increase their competitiveness [1]. At present, academic institutions think of students as their main customers and seek to satisfy them by improving the service quality they provide [2]. A service quality improvement approach sets up a trust and satisfaction relationship. And a satisfied customer is a customer who will have positive recommendation actions for the organization [3].

Moreover, several approaches to service quality coexist. Reeves and Bednar [4] identify four approaches to determining service quality: quality as value [5], quality as excellence [6], quality as compliance with specifications [7] and quality as disconfirmation of expectations [8-10]. According to these different conceptions, quality has two main meanings:
_ $\quad$ "objective" quality, where quality is measured against clear and predefined standards; and

- "subjective" quality, which is based on the customer's or user's viewpoint.

This approach has been developed in the services field where the characteristics of intangibility, immateriality, inseparability, indivisibility and non-storage ... have made it difficult to define objective criteria for quality measurement. Thus, this last meaning allows to assess the quality perception by customers or users according to their expectations. These expectations constitute personal standards of comparison. Moreover, recent literature dealing with university pedagogy has often insisted on the importance of collecting students' perceptions of the quality of services received [11,12].

In the service field, the link between perceived quality and satisfaction has been widely investigated and three main insights emerge. First, perceived service quality is presented as an antecedent to satisfaction [13]. Second, satisfaction is argued to be an antecedent of perceived quality [14]. Third, there would be no relationship between the two constructs [15]. Service quality and student 
satisfaction are therefore two variables that have a direct influence on the continuity and survival of an organization [16]. Service quality then becomes a key factor of competitiveness, and student satisfaction becomes a key determinant of service quality.

In contrast, in higher education, although there is some disagreement about the factors that make up perceived quality, many studies support the likely link between these two constructs [17-20].

In light of this theoretical framework, our purpose is to assess the training quality of Moroccan education inspectors through perceived quality and student satisfaction. First, we examine which quality attributes need to be further targeted in the TD at CFIE. Second, we test for potential causal relationships between perceived quality of service and student satisfaction.

It is therefore important to identify the determinants of service quality provided at CFIE and the key predictors of student satisfaction. In the present research, we put forward the general hypothesis of a causal link between "perceived quality" and "satisfaction". Thus, the quality of training at the CFIE in Rabat is studied according to the five dimensions of the SERVPERF model: Tangibility, Reliability, Responsiveness, Assurance and Empathy.

Accordingly, these five variables feed our following specific hypotheses:

H1: Tangible elements of the training device (TD) have a significant impact on student-inspectors' satisfaction.

H2: The TD's reliability has a significant impact on student-inspectors' satisfaction.

H3: Responsiveness has a significant impact on student-inspectors' satisfaction.

H4: The assurance provided by the TD has a significant impact on the student-inspectors' satisfaction.

H5: Empathy of CFIE staff has a significant impact on student-inspectors' satisfaction.

\section{Literature REVIEW}

The literature has often confused confused perceived service quality with service satisfaction: the concepts "service quality" and "satisfaction" are now used interchangeably"[21]. The definitions attributed to perceived quality, such as the one presented by [9], who consider it to be the result of a confrontation between the consumer's perceptions and expectations, seem to support this confusion. In response to this confusion, several researchers have examined the problems raised by the concepts of perceived quality and satisfaction, and have attempted to distinguish them [14, 22, 23].

In this section, we differentiate between these two constructs, trying to be more exact regarding their measures and dimensions. Then, we identify the main theoretical models of each.

\section{A. Service Quality}

Service quality is a concept that has generated considerable interest and debate in the literature, due to the difficulty of defining and measuring it without any general consensus [24]. The customer-based approach assumes that quality is not an objective thing, but is in the eyes of the beholder $[8,25]$. It is also widely accepted that service quality depends on the two factors: the expected service and the perceived service. [26] found that perceived service quality is the result of an assessment process where the expected service is compared to the received service.

Furthermore, it is known that service quality is based on multiple dimensions [10], [8]; but there is also no general agreement on the number, nature, or content of these dimensions $[27,28]$.

\section{1) Service quality dimensions}

Two schools of thought have emerged in the definition of service quality: the European and American schools. The European school defined service quality by dividing the concept into three dimensions. Thus, Lehtinen and Lehtinen [29] defined service quality in terms of physical quality, interactive quality and corporate quality. Physical quality is related to the tangible aspects of service. Interactive quality involves the interpersonal nature of services, and refers to the two-way flow that occurs between the customer and the service provider, including digital and automated interactions. Corporate quality refers to the image attributed to a service provider by its current and potential customers. They also suggest that, compared to the other two dimensions, corporate quality tended to be more stable over time. While Grönroos [10] identifies two dimensions of service quality, the technical aspect ("what" service is provided?) and the functional aspect ("how" the service is provided?). Customers perceive what they receive as the quality of the process result, i.e., the technical quality. However, the customer also perceives how the process itself works, i.e., the functional dimension or process quality. For some services, the "what" (or technical quality) may be difficult to assess. Unable to assess technical quality, service consumers rely on other measures of quality attributes associated with the service delivery process (the "how").

At the time, this was the first attempt to introduce a true model for measuring perceived service quality. However, the main criticism was the lack of explanations for measuring technical quality and functional quality. If European researchers suggest that outcome quality is a dimension of service quality, then American researchers perceive it as a dimension of customer satisfaction. For this reason, their measure of service quality does not explicitly reflect both dimensions, but only the functional dimension. According to this American school [30], service consumers consider five dimensions in their assessments of service 
quality, namely: tangibility, reliability, responsiveness, assurance and empathy.

Based on these dimensions, Parasuraman and al [30] developed the first instrument for measuring service quality, called "SERVQUAL", which evaluates both customers' perceptions (22 items) and expectations (22 items) [31].

TABLE I. SERVQUAL INSTRUMENT DIMENSIONS

\begin{tabular}{|c|l|c|}
\hline Dimensions & \multicolumn{1}{|c|}{ Definitions } & Items \\
\hline Tangibility & $\begin{array}{l}\text { Physical facilities, equipment, buildings } \\
\text { and personnel appearance. }\end{array}$ & 4 \\
\hline Reliability & $\begin{array}{l}\text { Ability to perform promised services on } \\
\text { time, accurately, confidently and } \\
\text { consistently. }\end{array}$ & 6 \\
\hline $\begin{array}{c}\text { Responsiveness, } \\
\text { helpfulness or } \\
\text { readiness }\end{array}$ & $\begin{array}{l}\text { Willingness to assist and serve } \\
\text { customers quickly. Eagerness to } \\
\text { respond to customers and provide } \\
\text { prompt service. }\end{array}$ & 3 \\
\hline Assurance & $\begin{array}{l}\text { Skills, knowledge, credibility, } \\
\text { politeness and courtesy of staff, and } \\
\text { their ability to inspire confidence and } \\
\text { security. }\end{array}$ & 4 \\
\hline Empathy & $\begin{array}{l}\text { Consideration for the customer, ability } \\
\text { to listen, to understand the customer's } \\
\text { concerns and needs, ability to mpathize } \\
\text { with the customer, communication } \\
\text { skills, and personal attention that the } \\
\text { entity gives to its customers. }\end{array}$ & 5 \\
\hline
\end{tabular}

According to Shafiq and al. [32], ServQual is accepted as a standard for assessing different dimensions of service quality and has been validated for a number of service institutions. It is a reference in service marketing [33,34], and inspires a wide range of research on service quality measurement in the public sphere [35-37]. Similarly, Adil [38] also concluded that ServQual provides a robust categorization of service dimensions.

However, other researchers have criticized it for focusing on the process of service delivery rather than the outcomes [39]. They also show that, in the vast majority of cases, the ServQual model is passively applied to the public sector without taking into account the specificities of the application domain, namely higher education and executive training. Furthermore, it has been argued that the five ServQual dimensions are not universal. Babakus and Boller [40] stated that "the field of service quality can be complex in some structures and sectors, and very simple and single-dimensional in others. Indeed, they state that the number and nature of the service quality dimensions depend on the type of service offered and the sector of activity.

Also, from a methodological viewpoint, Cronin and Taylor [41] consider SERQUAL (with 44 items) unreliable because it's almost impossible to measure expectations and perception at the same time.

2) Other conceptual service quality models

Cronin and Taylor [5] suggest that service quality is best predicted by performance only and not by the gap between performance and expectations. They argued that service quality is a customer attitude and that service performance is the sole indicator of service quality. In their 22 items SERVPERF model, they proceeded to measure only performance (perceived service) via the same quality dimensions used in SERVQUAL by Parasuraman et al. [8, 9], namely: tangibles, reliability, responsiveness, assurance and empathy. Cronin and Taylor [41] have shown that SERVPERF is a more accurate measure of service quality than ServQual.

Other researchers have also pointed out that instead of comparing, via ServQual, customers' expectations and perceptions of the services provided, it is better to measure exclusively the perceived service quality supplied. The latter has proven to be sufficient and useful [42]. Swartz, and Brown [43] attempted to synthesize the service quality dimensions by illustrating the work of Grönroos [10,29] and Parasuraman et al [8]. Their main contribution was to identify the service quality dimensions based on the literature review and categorize them as "What" (service assessed after delivery) and "How" (service assessed during delivery). However, their work does not reflect Grönroos' conceptualization of service quality perception [44], which emphasizes the role of the institution's brand image as a filter in the service quality perception.

While Haywood-Farmer identified three dimensions of service quality, called the "3P of service quality": (1) physical facilities and processes; (2) behavior of staff on duty; and (3) professional judgment of the duty staff in providing quality service. He stated that "an appropriate and carefully balanced mix of these three elements must be achieved" [45].

Another conceptualization of service quality was proposed by Rust and Oliver [46]. According to them, the overall perception of service quality is built on three dimensions: (1) the customer-staff interaction; (2) the service environment; and (3) the outcomes.

Although research supports the assertion that the service environment affects perceptions of service quality [47], it is difficult to distinguish the notion of service environment from the concept of functional quality suggested in the literature. For example, Brady and Cronin [27] proposed three factors comprising the service environment: ambient conditions, facility design, and social factors. However, Brady and Cronin [27] suggest that the service environment is a constituent of the service delivery process. In summary, and for parsimony, it seems preferable to include the elements of the service environment as components of the functional dimension.

Dabholkar, Thorpe, and Rentz [48] proposed and tested a multilevel model of service quality.

According to them, the main dimensions of service quality are: Physical aspects, Reliability, Personal interaction, Problem solving and Policy. The subdimensions for the first three dimensions are: appearance and convenience for the physical aspect; keeping promises 
and doing a good job for the reliability dimension; and projecting a sense of trust and courtesy/helpfulness for the personal interaction dimension.

In addition, Brandy and Cronin [27] developed a hierarchical service quality construct, based on four models: the Grönroos model [10], the ServQual model [9], the three-component model of Rust and Oliver [46], and the multilevel model of the Dabholkar and al. [48]. Their hierarchical approach involves three main dimensions: (1) interaction quality, (2) physical environment quality and (3) outcomes quality. Interaction quality concerns the parameters of attitude, behavior, and expertise of service providers and customers. The physical environment encompasses ambient conditions, service space design, and social factors. The outcomes quality takes into consideration waiting time, tangible elements of the service, and "valence" defined in terms of the relative ability to empathize, respond or serve.

Finally, in their hierarchical model, Brady and Cronin [27] used three tertiary sub-dimensions (reliability, responsiveness, and empathy), under each secondary dimension. These sub-dimensions were retained and identified as indirect indicators of the secondary dimensions and not direct determinants of service quality. In sum, the table below attempts to summarize the main conceptual models of service quality and their respective dimensions.

TABLE II. QUALITY DIMENSIONS ACCORDING TO THE CONCEPTUAL MODELS.

\begin{tabular}{|c|c|}
\hline Autors & Quality dimensions \\
\hline $\begin{array}{l}\text { Lehtinen \& Lehtinen } \\
\quad[29]\end{array}$ & $\begin{array}{l}\text { 1. Physical quality (the tangibles aspects of service). } \\
\text { 2. Interactive quality (process quality). } \\
\text { 3.Corporate quality (brand image and notoriety). }\end{array}$ \\
\hline Grönroos [49] & $\begin{array}{ll}\text { 1. } & \text { Technical aspect ("what"). } \\
\text { 2. } & \text { Functional aspect ("how"). } \\
\text { 3. } & \text { Corporate image (notoriety). }\end{array}$ \\
\hline $\begin{array}{l}\text { Parasuraman and al. } \\
{[8,9,30]}\end{array}$ & $\begin{array}{l}\text { 1. Tangible elements: physical facilities, equipment, materials, and personnel appearance. } \\
\text { 2. Reliability: ability to perform the promised service confidently and accurately. } \\
\text { 3. Responsiveness: Serviceability, Helpfulness, Readiness, willingness to respond to customers and provide prompt } \\
\text { and speedy services. } \\
\text { 4. Assurance (including skills, courtesy, credibility and safety): knowledge and politeness of employees and their } \\
\text { ability to inspire confidence. } \\
\text { 5. Empathy (including access, communication, understanding of the customer): consideration, individualized attention } \\
\text { given to customers. }\end{array}$ \\
\hline Swartz \& Brown [43] & $\begin{array}{l}\text { 1. "What" (service evaluated after performance). } \\
\text { 2. "How" (service assessed during the process). }\end{array}$ \\
\hline Cronin \&Taylor [27] & Same factors as in Parasuraman and al. [8]. \\
\hline Rust \& Oliver [46]. & $\begin{array}{l}\text { 1. Customer-employee interaction (functional quality or process quality). } \\
\text { 2. Service environment (physical and social factors). } \\
\text { 3. Result (technical quality). }\end{array}$ \\
\hline $\begin{array}{l}\text { Dabholkar, Thorpe \& } \\
\text { Rentz [48] }\end{array}$ & $\begin{array}{l}\text { 1. Physical aspects (appearance, suitability and convenience). } \\
\text { 2. Reliability (keeping promises and doing things right). } \\
\text { 3. Personal interaction (confidence, courtesy, helpfulness). } \\
\text { 4. Problem solving. } \\
\text { 5. Policy. }\end{array}$ \\
\hline Brady \& Cronin [27] & $\begin{array}{l}\text { 1. Interactive quality (attitude, behavior and expertise). } \\
\text { 2. Quality of the physical environment (ambient conditions, design and social factors). } \\
\text { 3. Quality of the outcome (waiting time, tangibles and valence, ability to unite, respond, react or serve). }\end{array}$ \\
\hline
\end{tabular}

According to the above table, the process dimension is present in all models; the result dimension (technical quality) is mentioned in five models; the corporate image is present in two models; equity in one model and value in one model.

In summary, although a number of studies have been conducted on service quality, no general agreement on the number, content, and nature of the dimensions is established in the literature. In many published studies, the service components assessed by customers using satisfaction instruments, generally leave open the question of whether these dimensions are exhaustive or are those that most matter to service beneficiaries. For example, ServQual-the most widely used instrument-has been criticized by many researchers for its focus on functional quality and process [50-54]

In this context, several models that include the outcome dimension, such as the Gronroos model [10], the Rust and Oliver model [46], the multilevel model [48] and the hierarchical approach [27] are recommended. The literature also concludes that the number and nature of ServQual dimensions can be specific from one sector of activity to another.

While the original study by Parasuraman and al [9] proposed five "universal" dimensions to measure service quality in any sector, the vast majority of research reports a different number of dimensions [55]. In this vein, 
Worthington [56] suggests that those implementing customer satisfaction and service quality assessment instruments should be aware of the difficulties and complexities inherent to their theoretical underpinnings, and be cautious in their use in specific settings. Adaptation of generic models and instruments to the context is more than necessary.

\section{B. Customer satisfaction}

To evoke customer satisfaction is to refer to the gap between his perceived service (service provided) and his expectations (expected service). Satisfaction is a global judgment resulting from an accumulation of experiences over time $[21,57,58]$. Satisfaction reflects an individual's judgment resulting from the transformation of objective facts and observations into subjective judgments [59]. Management and marketing scholars highlight the importance of customer satisfaction to the success of an organization [60].

According to AFNOR [61], satisfaction is defined as, "a judgment, an opinion that the individual expresses about the service he or she has experienced." Recognizing that services are difficult to assess for many reasons, the most obvious is that users participate in the production of the service delivered. Marketing professionals such as Eiglier \& Langeard [62] and Gabriel and al. [63], have referred to this as "servuction". Organizations do not do "quality for quality's sake", but do it primarily to attract, appeal, and retain their customers on the one hand, and to compete with their rivals on the other. Customer satisfaction is the very basis of quality [64]. Measuring customer satisfaction is currently a managerial duty for any organization involved in the quality approach, the customer approach, the process approach and the continuous improvement approach.

It is even a requirement of the flagship standard in quality management: the ISO 90012018 edition. Customer satisfaction measurement (CSM) is a feedback exercise that seeks to find out "what customers think about their needs, expectations and experiences with the services they receive" and "enables organizations to check the extent to which they are improving customer satisfaction" [64].

Nevertheless, the concepts and theories underlying customer satisfaction and service quality measures are not particularly clear-cut, and the usefulness of these measures has been doubted on many occasions. In the following, we briefly review the main theoretical models of satisfaction.

\section{3) Theoretical models of satisfaction}

\section{a) Expectancy disconfirmation theory}

Expectancy disconfirmation theory argues that clients make satisfaction judgements by evaluating the effective performance of the service in relation to their prior expectations. Several theoretical perspectives have been used to explain the relationship between disconfirmation and dissatisfaction [65]. The discrepancy theory is the most widely adopted and defines satisfaction as the difference between what is expected and what is perceived [66].
Satisfaction (positive discrepancy) occurs when the service is better than expected.

In contrast, a worse-than-expected performance generates dissatisfaction (negative invalidation). Not all existing researches demonstrate an association between desires and satisfaction [67]. Consistency theory suggests that when the effective performance of the service does not match expectations, the consumer will feel some tension.

To overcome this tension, the consumer will try to adjust both expectations and perceptions of the actual service performance. There are several coherence theories approaches [68]: (1) assimilation theory; (2) contrasting theory; (3) assimilation-contrast theory; and (4) negativity theory.

Assimilation theory, based on Festinger's cognitive dissonance theory [69], suggests that inconsistencies between expectations and outcomes will be reduced or assimilated in order to bring perceptions of outcomes in line with expectations [70,71].

According to Anderson [65], customers seek to avoid dissonance by adjusting perceptions about a given service to make it more consistent with expectations. Customers can also reduce the tension resulting from a gap between expectations and service performance, either by distorting expectations to coincide with perceived service performance or by increasing satisfaction.

Contrast theory suggests that when customers perceive a gap between expectations and outcomes, they magnify the difference. Assimilation-contrast theory holds that both paradigms - assimilation and contrast - are applicable to the study of customer satisfaction. This theory posits that the customer satisfaction response will be non-linear: when there is a gap between expectations and outcomes, assimilation will occur between the borders of the "tolerance zone", while outside this zone, the contrast effect will increase, leading to dissatisfaction or higher satisfaction than prescribed by the assimilation approach. Customer research appears to support the contrast and assimilation model [70]. The negativity theory, like the other three, is also based on the process of refutation. Developed by Carlsmith and Aronson [71], cited in [68], it suggests that any deviation in performance from expectations will upset the customer, producing "negative energy." Anderson [65] explains that when expectations are not confirmed, customers respond negatively to any information. Dissatisfaction occurs if perceived performance falls below expectations or if perceived performance exceeds expectations.

\section{b) Fullfilment theory}

Fullfilment theory comes from an older tradition of job satisfaction research which postulates that satisfaction is determined by the experience outcomes, whatever we feel, or wish to receive [72]. In the field of customer satisfaction research, expectation - rebutting factors and execution factors have been noted as predictors of satisfaction [73]. 


\section{c) Attribution theory}

The attribution dimension used in customer satisfaction research is represented by the construct of "causality locus " [74,59]. It is based on the proposal that a customer who attributes the cause of a "good" service to internal factors (e.g., his own abilities or efforts) will exhibit greater satisfaction than a customer who attributes a good service to external causes (e.g., material or environmental conditions). The study by Oliver and DeSabro [75] confirmed the statement that internal causal attributions are strongly related to satisfaction.

\section{d) Equity theory (fairness theory)}

This theory is built on the assumption that "Man's rewards in exchange with others should be proportional to his investments" [70]. In other words, the concept of equity suggests that the ratio of outcomes to inputs should be constant for all participants in an exchange. Applied to customer satisfaction research, satisfaction is thought to exist when the customer believes that his or her ratio of outcomes to inputs is equal to that of the exchange (e.g., seller). Studies suggest that equity has a moderate effect on customer satisfaction [73].

\section{e) Sociological perspectives on satisfaction}

The final theory under review examines the interactional and social aspects of the predictors of satisfaction. The sociological perspective examines the veracity of the theoretical link between expectations and satisfaction, mainly because the expectations refutation theory does not recognize the social context or social influences on customers. The results of various studies imply that an individual's social context, interpersonal relationships and power relationships between the service provider and clients must be incorporated into satisfaction modeling [56].

As a synthesis of the theories underlying customer satisfaction, while divergence theory (the paradigm of expectations refutation) is usually the most accepted and adopted, then other theoretical insights suggests that the satisfaction construct may itself be simplistic. In this respect, assimilation-contrast theory argues that factors such as the " tolerance zone " and contrast and assimilation effects should be incorporated into satisfaction models. Customer satisfaction also is influenced by the customer's perception of equity. It also appears that internal causes of "good service," defined in terms of customer ability or effort, are linked to higher satisfaction than external causes (e.g., material conditions). The sociological side suggests that customer satisfaction is also influenced by factors such as social and interactional dynamics, and by the power of service providers, as well as by wider social factors such as cultural factors, etc. These factors must also be captured in customer satisfaction models.

In the end, our literature review brought out several main conclusions. There is a growing consensus that the two constructs (service quality and satisfaction) differ in terms of the underlying causes, and the produced outcomes produced $[73,76]$. Although they have some things in common, satisfaction is generally considered a larger concept, while service quality assessment focuses specifically on the features, attributes and characteristics of the service. On this basis, perceived service quality is an integral part of customer satisfaction. Oliver [73] previously suggested that service quality would precede customer satisfaction.

Some researchers have found empirical findings to corroborate this insight [77-79]. In this logic, service quality is defined as a targeted evaluation reflecting the customer's perception of specific service characteristics and dimensions, whereas the notion of satisfaction is more inclusive, shaped by the perception of service quality, price and equity, as well as by personal and situational factors [76]. It should be noted that, in this sense, service quality is a perceived quality by the customer and not an objective characteristic of reality.

\section{MATERIALS AND METHOD}

Our study favors a quantitative, descriptive and exploratory approach. It solicited a population sample of 191 student inspectors who received training at the CFIE in Rabat for the 2019-2020 academic year. Our sample represents three different training branches (tracks): Inspectors of Material and Financial Services (ISMF), Inspectors of Secondary Qualifying Education (IESQ) and Inspectors of Primary Education (IEP). The respondents' selection is based on a non-probability convenience sampling method. $63 \%$ of the respondents were male and $37 \%$ were female, 117 respondents were between 31 and 40 years old, and 74 were between 41 and 45 years old. $44 \%$ of the respondents were first year students, $56 \%$ second year. It can be observed that the distribution of our respondents in first and second years of study is roughly equal.

We borrowed, adapted and applied Cronin and Taylor's SERVPERF instrument [5] to the specificities of the educational inspectors' training at the CFIE in Rabat. It is the most widely used and tested inspection tool for measuring service quality $[80,81]$. SERVPERF is a modification of SERVQUAL, and thus uses the same categories to assess service quality as an attitude and not as satisfaction. It adopts the dual idea that perceived service quality leads to satisfaction, and that satisfaction is linked to other quality dimensions.

Indeed, numerous empirical studies have applied the SERVPEREF instrument to measure service quality in different sectors [5,34,82-86]. Our SERVPERF measurement scale is therefore composed of two parts. The first consists of questions regarding the personal characteristics of our respondents, and the second was designed to inspect student inspectors' perceptions of service quality at CFIE. This second part consists of 22 items addressing the five SERVQUAL service quality 
dimensions (Tangibility, Reliability, Responsiveness, Assurance, and Empathy).

A five-point Likert scale ranging from "strongly disagree" to "strongly agree" was used to collect the data. Due to the quantitative and descriptive nature of SERVERF, frequencies, standard deviation and means were calculated. Correlation analysis was performed and the reliability of the instrument was tested.

\section{Results}

Internal consistency analysis of the SERVPERF scale shows that the Cronbach's Alpha value is highly acceptable $(\alpha=0.777)$ (Table 3$)$. It exceeds the minimum required threshold of 0.70 [87]. Thus, all five dimensions (tangibility, reliability, responsiveness, assurance, and empathy) show largely satisfactory values ranging from 0.723 relative to the dimension "Reliability" to 0.817 for the dimension "Empathy". The latter is considered the variable with the best internal consistency. Our measurement scale therefore has a highly satisfactory internal consistency.

TABLE III. INTERNAL CONSISTENCY VALUES OF THE DIMENSIONS OF THE SCALE ADAPTED FROM SERVPERF.

\begin{tabular}{|l|c|c|}
\hline Dimensions & No. of items & Cronbach Alpha \\
\hline Tangibility & 4 & 0.810 \\
\hline Reliability & 6 & 0.723 \\
\hline Responsiveness & 3 & 0.751 \\
\hline Assurance & 4 & 0.786 \\
\hline Empathy & 5 & 0.817 \\
\hline Total & 22 & 0.777 \\
\hline
\end{tabular}

The data analysis (Table 4 below) shows that student inspectors' perception of the "Tangibility" dimension ranges on average from 2.23 to 3.12 . The "Reliability" dimension ranges from 2.67 to 3.41 ; the "Responsiveness" dimension varies from 3.61 to 3.90 ; the dimension of "Assurance" ranges from 3.32 to 4.99 and the fifth dimension of "Empathy" ranges from 2.10 to 2.84.

TABLE IV. DESCRIPTIVE STATISTICS OF SERVPERF DIMENSIONS

\begin{tabular}{|l|c|c|}
\hline Dimensions & Mean* & S.D \\
\hline Tangibility & & \\
\hline The CFIE has modern looking equipment. & 2.23 & 0.095 \\
\hline The CFIE's physical facilities are visually appealing... & 2.34 & 1.02 \\
\hline The CFIE's employees are neat-appearing. & 3.12 & 1.1 \\
\hline $\begin{array}{l}\text { The teaching materials used are of sufficient number and } \\
\text { good quality. }\end{array}$ & 2.43 & 1.21 \\
\hline Reliability & & \\
\hline $\begin{array}{l}\text { When the CFIE promises to do something by a certain } \\
\text { time, it does so. }\end{array}$ & 3.33 & 0.96 \\
\hline $\begin{array}{l}\text { When you've a problem, the CFIE shows a sincere } \\
\text { interest in solving it. }\end{array}$ & 3.23 & 1.13 \\
\hline The CFIE performs the service right the first time. & 2.67 & 1.03 \\
\hline $\begin{array}{l}\text { The CFIE provides its services at the time it promises to } \\
\text { do so. }\end{array}$ & 2.54 & 1.1 \\
\hline $\begin{array}{l}\text { Employees of the CFIE tell you exactly when services } \\
\text { will be performed. }\end{array}$ & 3.41 & 0.095 \\
\hline The CFIE insists on error-free records. & 3.12 & 1.04 \\
\hline
\end{tabular}

\begin{tabular}{|l|c|c|}
\hline Responsiveness & & \\
\hline $\begin{array}{l}\text { Employees of the CFIE are never too busy to respond to } \\
\text { your requests. }\end{array}$ & 3.61 & 0.93 \\
\hline Employees of the CFIE give you the prompt service. & 3.82 & 1.05 \\
\hline Employees of the CFIE are always willing to help you. & 3.90 & 1.03 \\
\hline Assurance & & \\
\hline $\begin{array}{l}\text { The behaviour of employees of the CFIE installs } \\
\text { confidence in customers. }\end{array}$ & 4.23 & 1.04 \\
\hline $\begin{array}{l}\text { Employees of the CFIE are consistently courteous with } \\
\text { you. }\end{array}$ & 3.32 & 0.92 \\
\hline $\begin{array}{l}\text { Employees of the CFIE have the knowledge to answer } \\
\text { your questions. }\end{array}$ & 4.99 & 0.98 \\
\hline $\begin{array}{l}\text { The CFIE has operating hours convenient to all its } \\
\text { customers. }\end{array}$ & 3.66 & 1.32 \\
\hline Empathy & & \\
\hline $\begin{array}{l}\text { Employees of the CFIE have the knowledge to answer } \\
\text { your questions. }\end{array}$ & 2.43 & 0.97 \\
\hline $\begin{array}{l}\text { The CFIE has employees who gives you the personal } \\
\text { attention. }\end{array}$ & 2.10 & 0.99 \\
\hline The CFIE has your best interest at heart. & 2.34 & 1.42 \\
\hline Employees of the CFIE understand your specific needs. & 2.84 & 1.04 \\
\hline The CFIE has employees who are competent. & 2.54 & 1.01 \\
\hline
\end{tabular}

* Scores are averaged on a scale of $1=$ strongly disagree to $5=$ strongly agree.

The student inspectors' perception of the "Empathy" dimension is the least positive, compared to the other dimensions. Our respondents estimate that the CFIE staff does not make enough effort to understand students' expectations, needs and problems (cognitive empathy). They do not have enough compassion and they lack emotional empathy towards them. This shows that our respondents are heterogeneous and that their needs and expectations are also very diverse.

This difference in needs and expectations is well explained by the fact that our sample population represents three different educational tracks. It is therefore judicious for the CFIE to carry out segmentations of training services on the double basis of students' andragogical differentiation (differentiated andragogy) and on the curricular and professional specificity of each field of study.

To evaluate the structural model of our instrument, the determination coefficient (R2) of each dependent variable, the structural coefficients $(\beta)$, and the significance level (tvalue) were examined. The R2 values were above the recommended threshold of 0.10 (between 0.189 and 0.841 ) [88].

TABLE V. RESULTS OF THE STRUCTURAL EQUATION MODEL ESTIMATIONS.

\begin{tabular}{|l|c|c|c|c|c|c|}
\hline \multicolumn{1}{|c|}{ Dimensions } & $\mathbf{V}$ & $\mathbf{H}$ & $\mathbf{( \beta )}$ & $\begin{array}{c}\mathbf{t}- \\
\text { Value }\end{array}$ & $\begin{array}{c}\mathbf{p}- \\
\text { Values }\end{array}$ & $\mathbf{R}$ \\
\hline Tangibility & S & H1 & 0.487 & 13.019 & 0.000 & $\mathrm{C}$ \\
\hline Reliability & S & H2 & 0.816 & 21.787 & 0.000 & C \\
\hline Responsiveness & S & H3 & 0.763 & 17.638 & 0.000 & C \\
\hline Assurance & S & H4 & 0.613 & 10.732 & 0.000 & C \\
\hline Empathy & S & H5 & 0.385 & 3.185 & 0.002 & C \\
\hline
\end{tabular}

V: Explained variable; S: Satisfaction; H: Hypothesis; $(\beta)$ : Structural Coefficient; $\mathrm{R}$ : Result and C: confirmed. 
Table 5 shows that the five dimensions of perceived quality of SERVPERF (Tangibility, Reliability, Responsiveness, Assurance, and Empathy) significantly impact student-inspector satisfaction at CFIE ( $\beta=0.487, \rho$ $<0.005 ; \beta=0.816, \rho<0.005 ; \beta=0.763, \rho<0.005 ; \beta=0.613$, $\rho<0.005 ; \beta=0.385, \rho<0.005$ ). Therefore, all of our initial hypotheses hold true for the Rabat CFIE. The findings analysis also shows that there is a positive statistical significance between the three dimensions of quality (Reliability, Responsiveness and Assurance) and studentinspector satisfaction. In contrast, Pearson's correlative analysis shows that there is no significant relationship between the dimensions "Empathy" and "Tangibility".

\section{Discussion AND CONCLUSION}

Through perceived quality and student satisfaction, our study revealed the characteristic determinants of the quality of the training device at CFIE. According to our respondents, the perceived quality of services provided by CFIE is relatively acceptable. Nevertheless, it shows a need for improvement in the dimensions of Tangibility and Empathy. CFIE staff (managers and teachers) focus more on the three dimensions of "Reliability", "Responsiveness" and "Assurance" of the TD than on the other dimensions. While these three variables are necessary and useful for any TD, they are never sufficient when used alone. Service quality is therefore plural and determined by several dimensions, including at least five, those of SERVPERF.

As a consequence, the CFIE staff must focus on the tangible aspects of TD such as renewing equipment and updating teaching materials.

At the same time, according to Manyi Agbor [89], this research indicates that "empathy" dimension is also important and that managers should, where appropriate, conduct training sessions for staff to improve their communication skills and their ability to empathize with students in their feelings and experiences. Examination of the causal relationships, between our two constructs, highlighted the significant impact of service quality on student satisfaction. These results are in line with previous studies on the effect of service quality on customer satisfaction [1,90-92]. They all admit that TD performance has a significant effect on student satisfaction.

Applying the SERVPERF scale, the most important implication of this study is that CFIE managers must improve the parameters related to tangibles (physical equipment and facilities), and empathy (cognitive and emotional). They need to be more and more involved in these different dimensions to continue to attract the best student profiles, to better train them for inspection tasks, and to merit the status of the sole training center for inspectors in Morocco.

Thus, the SERVPERF scale is a valuable tool in the institutional assessment of the TD and in the implementation of a culture of continuous improvement within the CFIE. By applying this tool, among many others, it is possible to determine which dimension of quality needs to be prioritized and greatly improved $[5,93$, 40]. However, our research also has some limitations. It used a single tool that does not always receive consensus, especially in the training of educational leaders, managers and inspectors. Hence the risk of omitting other explanatory factors of "satisfaction". It would therefore be appropriate in future research to duplicate this study by borrowing other tools for measuring the service quality such as SERVQUAL, HEDPERF, PAKSERV or HiEdQUAL, and to verify which ones are adapted to the context of educational inspection in Morocco. In the same way, the training of education inspectors cannot be reduced to a simple "service". It cannot be considered as a product or as a service like any other. In this high value-added field (production, transmission, implementation, development and management of knowledge), there is active coproduction of knowledge between the teacher and the student-inspector [20], and immediate co-consummation of knowledge.

\section{REFERENCES}

[1] P. Sultan, and H. Yin Wong,"How service quality affects university brand performance, university brand image and behavioural intention: the mediating effects of satisfaction and trust and moderating roles of gender and study model", Journal of Brand Management, Palgrave Macmillan, vol. 26 (3), 2019, pp 332-347, May. J. Clerk Maxwell, A Treatise on Electricity and Magnetism, 3rd ed., vol. 2. Oxford: Clarendon, 1892, pp.68-73.

[2] T. Nguyen,"Essai de mesure de la qualité de service dans le contexte d'enseignement supérieur universitaire au Viêtnam". Faculté de gestion d'entreprises, Institut universitaire de technologie, de poste et de télécommunication, Viêtnam, 2012.

[3] C. Kouthouris, and K. Alexandris, "Can service quality predict customer satisfaction and behavioral intentions in the sport tourism industry? An application of the SERVQUAL model in an outdoors setting", Journal of Sport Tourism, Vol. 10 (2), pp. 101-11, 2005.

[4] C.A. Reeves, et D.A Bednar,"Définition de la qualité: alternatives et implications". Academy of Management Review, vol. 19, 419445, 1994.

[5] J.J., Cronin Jr., and S.A. Taylor,"Measuring service quality: a reexamination and extension". Journal of Marketing, Vol 56 (3), 55-69, 1992.

[6] R.M. Pirsig, (1992), “Lila: An inquiry into morals”. New York: Bantam Books, in Reeves \& Bednar, 1994.

[7] D. A. Garvin, "What Does Product Quality Really Mean? ". Sloan Management Review vol. 26.(1) : 25-43, 1984.

[8] A. Parasuraman, V. Zeithaml, and L. Berry,"A conceptual model of service quality and its implications for future research". Journal of Marketing, Fall, vol 49: 41-50, 1985.

[9] A. Parasuraman, V. Zeithaml, and L. Berry, "Servqual: a multi-item scale for measuring consumer perceptions of service quality". Journal of Retailing, Vol. 64, (1), pp. 12-40, 1988.

[10] C. Grönroos, "A service quality model and its marketing implications", European Journal of Marketing, Vol. 18, (4), 37-44, 1984.

[11] J.-M. De Ketele, “Évaluation des systèmes de formation”. In A. Jorro (dir.), "Dictionnaire des concepts de la professionnalisation" (p.117-120). Louvain-la-Neuve: De Boeck Supérieur, 2014).

[12] L. Endrizzi, “La qualité de l'enseignement : un engagement des établissements avec les étudiants ?", Dossier de veille de l'IFE, (93), 1-44, 2014. 
[13] J. Hutchinson, F. Lai, \& Y. Wang, "Understanding the relationships of quality, value, equity, satisfaction, and behavioral intentions among golf travelers". Tourism Management, 30, 298-308, 2009.

[14] M. J. Bitner,"Evaluating service encounters: the effects of physical surroundings and employee responses". Journal of Marketing, 54, April, 69-82. From Business Source Premier database, 1990.

[15] P. A. Dabholkar,"The convergence of customer satisfaction and service quality evaluations with increasing customer patronage". Journal of Consumer Satisfaction, vol.8 (31), 31-43, 1995.

[16] G.R., Gilbert, and C. Veloutsou, “A cross-industry comparison of customer satisfaction". The Journal of Services Marketing, Vol. 20 (5), pp. 298-308, 2006.

[17] M.K., Brady, C.J. Robertson, and J.J. Cronin,"Managing behavioral intentions in diverse cultural environments: an investigation of service quality, service value, and satisfaction for American and Ecuadorian fast-food customers". Journal of International Management, Vol. 7, pp. 129-49, 2001.

[18] G.R. Gilbert, C. Veloutsou, M.M.H. Goode, and L. Moutinho, "Measuring customer satisfaction in the fast food industry: a crossnational approach". The Journal of Services Marketing, Vol. 18 No. 5, pp. 371-83, 2004.

[19] H. Qin, and V.R. Prybutok,"Determinants of customer-perceived service quality in fast-food restaurants and their relationship to customer satisfaction and behavioral intentions".Quality Management Journal, Vol. 15 (2), pp. 35-50, 2008.

[20] D., Carnerud, \& I. Bäckström, “Four decades of research on quality: summarising, Trendspotting and looking ahead". Total Quality Management \& Business Excellence, 2019.

[21] P.V. Ngobo,"Les standards de comparaison et la gestion de la satisfaction des clients". Décisions Marketing, (13), 57-66, 1998.

[22] R. Bolton, et J. Drew, “A multistage model of customer's assessments of service quality and value". Journal of Consumer Research, 17, March, 375-385, 1994).

[23] J. Carman,"Consumer perceptions of service quality: an assessment of the SERVQUAL dimensions". Journal of Retailing, vol. 66 (1), Spring. From Business Source Premier database, 1990.

[24] M. Wisniewki,"Using SERVQUAL to assess customer satisfaction with public sector services". Managing Service Quality: An International Journal, vol 11(6) 380-388, 2001.

[25] M. Salgado, "La performance: une dimension fondamentale pour l'évaluation des entreprises et des organisations". HAL Id: hal00842219, 2013).

[26] C. Grönroos, "Préparation au marketing relationnel: contexte théorique et directions de mesure", Journal of Services Marketing, Vol. 31 (3), pp. 218-225, 2017.

[27] M.K., Brady, \& J.J. Cronin,"Some New Thoughts on Conceptualizing Perceived Service Quality: A Hierarchical Approach". Journal of Marketing - J MARKETING. 65. 34-49, 2001.

[28] M. Diene, S. Dieng, K. Drame, "Analyse des déterminants de la performance des entreprises en Afrique subsaharienne francophone: cas du Sénégal". Laboratoire de Recherches Economiques et Monétaires, 2015.

[29] U. Lehtinen, and J.R. Lehtinen, “A Study of Quality Dimensions”. Service Management Institute, 5, 25-32, 1982.

[30] A. Parasuraman, V. Zeithaml, and L. Berry,"Refinement and reassessment of the SERVQUAL scale". Journal of retailing, 67. 420-450, 1991.

[31] V.A. Zeithaml, A. Parasuraman, and L.L. Berry,"Delivering quality service; Balancing customer perceptions and expectations". The Free Press, New York, NY, 1990.

[32] A. Shafiq, M.I. Mostafiz, M. Taniguchi,"Using SERVQUAL to determine Generation Y's satisfaction towards hoteling industry in Malaysia”. J. Tour. Futures, 5, 62-74, 2019.
[33] J. Rezaei, O. Kothadiya, L. Tavasszy, and M. Kroesen, “Quality assessment of airline baggage handling systems using SERVQUAL and BWM". Tour. Manag. 66, 85-93, 2018.

[34] S. Gounaris, "Measuring service quality in B2B services : an evaluation of the SERVQUAL scale vis-à -vis the INDSERV scale", Journal of Services Marketing, Vol. 19, (6), pp. 421-35, 2005.

[35] A. Meesala, \& J. Paul,"Service quality, consumer satisfaction and loyalty in hospitals: Thinking for the future". Journal of Retailing and Consumer Services, 40, 261-269, 2018.

[36] Y.L. Wang, T. Luor, P. Luarn, and H.P. Lu, “Contribution and trend to quality research-a literature review of SERVQUAL model from 1998 to 2013”. Inform. Econ. 19, 34-45, 2015.

[37] R. Rosha \& D. N. Kaur,"Relationship between RATER Service Quality Dimensions and Customer Satisfaction-Study on Travel Agents in Punjab". Researchers World, vol. 9 (1), 160, 2018.

[38] M. Adil,"The relationship between service quality and customer satisfaction in India's rural banking sector: An item analysis and factor-specific approach”. The Lahore Journal of Business, Vol. 1, (2), pp. 43-63, 2013.

[39] R. Ladhari, “A review of twenty years of SERVQUAL research", International Journal of Quality and Service Sciences, vol. 1, (2), pp. 172-198, 2009.

[40] E. Babakus, \& G.W. Boller,"An Empirical Assessment of the SERVQUAL Scales", Journal of Business Research, 24: 253-68, 1992.

[41] J.J. Cronin Jr, and S.A. Taylor,"SERVPERF vs. SERVQUAL: reconciling performance based and perceptions-minusexpectations measurement of service quality. Journal of Marketing, vol. 58 (1), 125-131, 1994.

[42] N. Seth, SG. Deshmukh, \& P. Vrat,"Modèles de qualité de service: une revue". International Journal of Quality \& Reliability Management, vol. 22 (9), pp. 913-949, 2005.

[43] T.A. Swartz, and S.W. Brown,"Consumer and provider expectations and experiences in evaluating professional service quality". JAMS 17, 189-195, 1989.

[44] C. Grönroos,"Gestion des services : une orientation de gestion pour la concurrence des services". Revue internationale de gestion de l'industrie des services, vol. 1 (1), pp. 6-14, 1990.

[45] J. Haywood-Farmer,"Un modèle conceptuel de qualité de service". Revue internationale des opérations et de la gestion de la production , vol. 8 (6), pp. 19-29, 1988.

[46] R.T. Rust, and R.L. Oliver,"Service Quality: Insights and Managerial Implications from the Frontier. In: Rust, RT et Oliver, RL, Eds., Service Quality: New Directions in Theory and Practice, Sage Publications, Thousand Oaks, 1-19, 1994.

[47] E.R. Spangenberg, A.E. Crowley, and P.W. Henderson,"Improving the store environment: do olfactory cues affect evaluations and behavior?". Journal of Marketing, 60, pp. 67-80, 1996.

[48] P.A. Dabholkar, D.I. Thorpe, \& J.O. Rentz, “A measure of service quality for retail stores: Scale development and validation. JAMS 24, (3), 1996.

[49] C. Grönroos,"An Applied Service Marketing Theory", European Journal of Marketing. Vol. 16 (7), pp. 30-41, 1982.

[50] A. Baldwin, and A. Sobhal, "Service quality factors and outcomes in dental care. Managing Service Quality", vol. 13 (3), 207- 216, 2003.

[51] K. Choi, H. Lee, C. Kim, \& S. Lee,“The service quality dimensions and patient satisfaction relationships in South Korea: Comparisons across gender, age and types of service. Journal of Services Marketing. 19. 140-149, 2005.

[52] A. Curry, \& E. Sinclair,"Assessing the quality of physiotherapy services using SERVQUAL". International Journal of Health Care Quality Assurance. 15. 197-205, 2002. 
[53] S. Jain, \& G. Gupta,"Measuring Service Quality: Servqual vs. Servperf Scales". Vikalpa: The Journal for Decision Makers, 29, 25 $-38,2004$.

[54] G-D. Kang, \& J. Jeffrey,"Service quality dimensions: An examination of Gronroos's service quality model". Managing Service Quality. 14. 266-277, 2004.

[55] M. Morales, S. Nyeck, R. Ladhari, \& F. Pons,"10 years of service quality measurement: Reviewing the use of the SERVQUAL instrument". Cuadernos de Difusion. 7. 101-107, 2002.

[56] C. Worthington,"Patient Satisfaction with Health Care: Recent Theoretical Developments and Implications for Evaluation Practice”. The Canadian Journal of Program Evaluation, vol. 20 (3): 41-63, 2005.

[57] E. Garbarino, \& M. Johnson, “The Different Roles of Satisfaction, Trust, and Commitment in Customer Relationships". Journal of Marketing. Vol. 63. (10), 1999.

[58] A. Jamal, and K. Naser,"Customer satisfaction and retail banking: an assessment of some of the key antecedents of customer satisfaction in retail banking". International Journal of Bank Marketing, Vol. 20 (4), pp. 146-160, 2002.

[59] J. Vanhamme, "La satisfaction des consommateurs spécifique à une transaction : définition, antécédents, mesures et modes". Recherche et Applications en Marketing, vol. 17 (2), 55-85, 2002.

[60] J. McColl-Kennedy, \& U. Schneider,"Measuring customer satisfaction : Why, what and how?". Total Quality Management. 11. 883-889, 2000.

[61] AFNOR, ISO 18091 (2019). Systèmes de management de la qualité — Lignes directrices pour l'application de l'ISO 9001 à la collectivité locale. Comité technique: ISO/TC 176. Management et assurance de la qualité. 2ème éd, 2019.

[62] P. Eiglier, \& E. Langeard,"Servuction. Le marketing des services", McGraw Hill. (1987).

[63] P. Gabriel, R. Divard, M. Le Gall-Ely, I. Prim-Allaz,"Marketing des services", Ed. Dunod, 2014.

[64] France Qualité Publique,"Evaluer la qualité et la performance publique", La documentation Française, 2006.

[65] R.E. Anderson, "Consumer Dissatisfaction: The Effect of Disconfirmed Expectancy on Perceived Product Performance". Journal of Marketing Research, vol. 10 (2), p. 38-44, 1973.

[66] L. Festinger,"A theory of social comparison processes". Human Relations, 7, 117-140, 1954.

[67] J. Sitzia, and N. Wood,"Patient satisfaction: A review of issues and concepts”. Social Science and Medicine, 45, 1829-1843, 1997.

[68] R.M. Peyton, S. Pitts, \& R. H. Kamery,“A review of significant consumer satisfaction/dissatisfaction models: the family decisionmaking process". Proceedings of the Academy of Family Business, vol. 1, 2003.

[69] L. A. Festinger, “A Theory of Cognitive Dissonance”, Row \& Peterson, Evanston IL, 111, 1957.

[70] R.L. Oliver,"Processing of the Satisfaction Response in Consumption: A Suggested framework and Research Propositions". Journal of Consumer Satisfaction, Dissatisfaction and Complaining Behavior 2, 1-16, 1989.

[71] J.M. Carlsmith, and E. Aronson, "Some hedonic consequences of the confirmation and disconfirmation of expectancies". Journal of Abnormal and Social Psychology, 66, fév, 151- 56, 1963.

[72] E., Lawler, \& J. Suttle, "Expectancy theory and job behavior". Organizational Behavior and Human Performance, vol. 9 (3), 482503, 1973.

[73] R.L. Oliver, "Cognitive, affective and attribute bases of the satisfaction response". Journal of Consumer Research, vol. 20, p. 418-430, 1993.
[74] R. Ladhari, "La satisfaction du consommateur, ses déterminants et ses conséquences. Revue de l'Université de Moncton, vol. 36 (2), 171-201, 2005.

[75] R. L. Oliver, and W. S. DeSarbo, "Response Determinants in Satisfaction Judgments." Journal of Consumer Research, 14 (March), 495-507, 1988.

[76] A. Wilson, V. Zeithaml, M. Bitner, and D. Gremier, Services Marketing: integrating customer focus across the firm. First European Edition. McGraw Hill, UK, 2008.

[77] E. Anderson, \& M. Sullivan, "The Antecedents and Consequences of Customer Satisfaction for Firms". Marketing Science, vol. 12(2), 125-143, 1993.

[78] C.G. Fornell, M.D. Johnson, E.W. Anderson, J. Cha, \& B.E. Bryant,"The American Customer Satisfaction Index: Nature, purpose, and findings". Journal of Marketing, vol. 60 (4): 7-18, 1996.

[79] R. A. Spreng, Mackenzie, S. B. \& Olshavsky, R. W. "A reexamination of the determinants of consumer satisfaction", Journal of Marketing, 60, 15-32, 1996.

[80] A. Brochado,"Comparing alternative instruments to measure service quality in higher education". Quality Assurance in Education, vol. 17(2), 174-190, 2009.

[81] A. Firdaus, "Measuring service quality in higher education: HEdPERF versus SERVPERF". Marketing Intelligence \& Planning, vol. 24(1), 31-47, 2006.

[82] D.C. Bojanic, and D.L. Rosen,"Measuring service quality in restaurants: an application of the SERVQUAL instrument". Hospitality Research Journal, vol. 18 (1) pp. 3-14, 1994.

[83] Y.Y. Fu, and S.C. Parks, "The relationship between restaurant service quality and consumer loyalty among the elderly". Journal of Hospitality \& Tourism Research, vol. 25 (3), pp. 320-6, 2001,

[84] T. Pawitra, \& K. Tan, "Tourist Satisfaction in Singapore- A Perspective from Indonesian Tourists. Managing Service Quality, vol 13(5): 399-411, 2003.

[85] V.C.S. Heung, M.Y. Wong, and H. Qu, "Airport-restaurant service quality in Hong Kong: an application of SERVQUAL". Cornell Hotel \& Restaurant Administration Quarterly, Vol. 41 (3), pp. 8696, 2000).

[86] M. Lee, and F.M. Ulgado,"Customer evaluation of fast-food services: a cross-national comparison". The Journal of Services Marketing, Vol. 11 (1), pp. 39- 52, 1997.

[87] J. C. Nunnally, Psychometric theory (2nd ed.). New York: McGraw-Hill, 1978.

[88] R. Falk, \& N. Miller, “A Primer for Soft Modeling”. The University of Akron Press: Akron, OH 1992.

[89] J. Manyi Agbor,"The Relationship between Customer Satisfaction and Service Quality: a study of three Service sectors in Umeå", Master UMEA University, 2011.

[90] H. Afzal, I. Ali, M. Khan, \& K. Hamid,“A Study of University Students: Motivation and Its Relationship with Their Academic Performance". International Journal of Business and Management, vol. 5(4), 80-88, 2010.

[91] F. Abdullah,"Measuring Service Quality in Higher Education: Three instruments compared". International Journal of Research \& Method in Education, 29. 71-89, 2006.

[92] J. Hanaysha, A. Haim hilman, \& A. Warokka, "Service Quality and Students' Satisfaction at Higher Learning Institutions: The Competing Dimensions of Malaysian Universities' Competitiveness”. The Journal of Southeast Asian Research, 2011.

[93] W. Boulding, A. Kalra, R. Staelin, and V. A. Zeithaml,“A Dynamic Process Model of Service Quality: From Expectations to Behavioral Intentions". Journal of Marketing Research, Vol. 30, pp. 7-27. February, 1993. 